\title{
HUBUNGAN ANTARA TINGKAT PENDIDIKAN, PEKERJAAN DAN PENGETAHUAN IBU TENTANG IMUNISASI DENGAN KEBERHASILAN PEMBERIAN IMUNISASI DASAR PADA BAYI
}

\author{
Warsini ${ }^{1}$, Kevin Anung Joseptian ${ }^{2}$
}

\begin{abstract}
Background: It is undoubted if basic immunization has benefited immensely to child for over the years. Nevertheless there aresome parents who remains reluctant to immunize their children. This condition could be proved by the achievement of $\mathrm{UCI}$ (Universal Child Immunization) in 2015 in Klaten which involved 401 villages. There was only $90 \%$ of the total population who participated in this program.

The Purpose: To analized the relationship between education level, work satus and mother's knowledge about basic immunization with the successness of giving basic immunization to babies.

The Subjects: The study was observational analytic with cross sectional design. The population were all mothers who had infants aged 9-12 months in January-February 2018 in Wonosari District taken using total sampling technique. The data was then collected by using questionnaires.

The results: Most of the infants were 11 months old (50\%), most of mother were 25-35 years old $(66.8 \%)$, most of the mother's education level was Senior High School (46.7\%), most of the mother's knowledge about immunization was high (96.7\%), the majority of mothers did not work (53.3\%), most infants were fully immunized (96.7\%). Chi Square analysis found that the correlation between education level and the successness of immunization in infant $p=0.245$, work relation with success of immunization giving to infant $p=0.341$, and relation of mother knowledge about basic immunization with successness immunization giving to infant $p=0.000$.

The conclusion: There was no correlation between the level of education with the successness of immunization in infants $(p=0.245)$, there was no relationship between work status with successness immunization in infants $(p=0.341)$, and there was a statistically significant relationship between maternal knowledge of basic immunization with successness immunization in infants $(p=0.000)$.
\end{abstract}

Keywords: basic immunization, education, employment, knowledge

\section{PENDAHULUAN}

Imunisasi merupakan salah satu upaya melindungi tubuh dari penyakit. Imunisasi sangat diperlukan untuk memberikan perlindungan dan pencegahan, sekaligus membangun kekebalan tubuh terhadap berbagai penyakit menular maupun penyakit berbahaya yang dapat menimbulkan kecacatan tubuh bahkan kematian. Banyak manfaat pemberian imunisasi dasar. Menurut Kumalasari (2015), manfaat pemberian imunisasi dasar adalah mencegah terjadinya penyakit infeksi, mampu mencegah gejala yang dapat menimbulkan cacat atau kematian dan dapat menghilangkan penyakit tertentu pada sekelompok masyarakat (populasi) bahkan menghilangkan penyakit tertentu dari dunia seperti pada imunisasi cacar.

Meskipun banyak manfaat imunisasi masih ada orangtua yang enggan mengimunisasikan anaknya karena memandang tidak penting. Sebagai contoh adalah hasil penelitian Mulyanti (2013) di wilayah kerja Puskemas Situgintung Ciputat diketahui sebanyak $14 \%$ orang tua tidak memberikan imunisasi dasar lengkap. 
Imunisasi merupakan salah satu cara pencegahan penyakit menular khususnya penyakit yang dapat dicegah dengan imunisasi (PD3I) yang diberikan tidak hanya kepada anak sejak masih bayi hingga dewasa, tetapi juga kepada orang dewasa. Cara kerja imunisasi yaitu dengan memberikan antigen bakteri atau virus tertentu yang sudah dilemahkan atau dimatikan dengan tujuan merangsang sistem imun tubuh untuk membentuk anti bodi (Suryanti dan Badi'ah, 2014).

Menurut profil kesehatan Kabupaten Klaten (2015), strategi operasional pencapaian cakupan tinggi dan merata berupa pencapaian Universal Child Immunization (UCI) yang berdasarkan indikator imunisasi dasar lengkap dengan cakupan minimal $85 \%$ dari jumlah sasaran bayi di desa. Pencapaian desa UCI tahun 2015 di Kabupaten Klaten sejumlah 401 desa adalah sebesar 90\%. Cakupan imunisasi di Kabupaten Klaten pada tahun 2015 adalah $\mathrm{HbO}: 16.592(97,59 \%), \mathrm{BCG}$ : 16765 (98,61\%), DPT-Hb3-/DPTHB-Hib : 16.875 (99\%), Polio 4 : 16.880 (98,66\%), Campak : 17.880 $(99,41 \%)$.

Keberhasilan pemberian imunisasi dasar pada bayi di Kabupaten Klaten belum mencapai $100 \%$. Salah satu kecamatan di wilayah Kabupaten Klaten dengan capaian imunisasi yang masih belum memuaskan adalah Kecamatan Wonosari. Kurang maksimalnya capaian tersebut bisa disebabkan oleh banyak faktor. Faktor-faktor tersebut sudah pernah diteliti oleh Mulyanti (2013), yaitu di wilayah kerja Puskesmas Situgintung Ciputat yang meliputi : pengetahuan ibu yang kurang tentang imunisasi dasar pada bayi, tingkat pendidikan ibu dan pekerjaan ibu yang menyita banyak waktu untuk mengimunisasikan bayinya.

Berdasarkan survai awal di Kecamatan Wonosari dari 30 orang ibu yang memiliki bayi usia kurang dari 1 tahun masih ada 9 bayi yang belum mendapatkan imunisasi dasar lengkap. Menurut kader kesehatan di Kecamatan Wonosari rata-rata ibu berpendidikan SD dan SMP dan banyak diantara mereka yang meninggalkan anaknya untuk bekerja. Di Kecamatan Wonosari juga belum pernah dilakukan penelitian tentang faktor-faktor penyebab cakupan imunisasi tersebut belum maksimal. Dari latar belakang tersebut penulis tertarik untuk melakukan penelitian tentang faktor-faktor yang mempengaruhi keberhasilan pemberian imunisasi dasar pada bayi di Kecamatan Wonosari.

\section{TUJUAN PENELITIAN}

Untuk mengetahui hubungan antara tingkat pendidikan, pekerjaan dan pengetahuan ibu tentang imunisasi dengan keberhasilan pemberian imunisasi dasar pada bayi.

\section{DESAIN PENELITIAN}

Penelitian ini merupakan penelitian analitik observasional dengan desain korelasi yang bertujuan untuk mencari hubungan antara tingkat pendidikan, pekerjaan dan pengetahuan ibu tentang imunisasi sebagai variabel bebas dengan keberhasilan pemberian imunisasi dasar pada bayi sebagai variabel terikat. Teknik pendekatan yang digunakan adalah cross sectional.

\section{POPULASI, SAMPEL, DAN TEKNIK SAMPLING}

Populasi pada penelitian ini adalah seluruh ibu yang mempunyai bayi dengan usia 9-12 bulan pada bulan Januari-Februari 2018 di Kecamatan Wonosari.

Sampel pada penelitian ini adalah seluruh ibu yang mempunyai bayi dengan usia 9-12 bulan pada bulan Januari-Februari 2018 di Kecamatan Wonosari. 
Teknik sampling yang digunakan dalam penelitian ini adalah teknik sampling jenuh.

\section{HASIL PENELITIAN}

Berikut ini adalah hasil penelitian yang didapatkan, yaitu:

Tabel 1.

Karakteristik Responden

\begin{tabular}{|c|c|c|}
\hline Karakteristik & $\mathrm{n}$ & $\%$ \\
\hline \multicolumn{3}{|l|}{ Umur Bayi (bulan) } \\
\hline 9 & 1 & 3.3 \\
\hline 10 & 2 & 6.7 \\
\hline 11 & 15 & 50 \\
\hline 12 & 10 & 33.3 \\
\hline 13 & 2 & 6.7 \\
\hline \multicolumn{3}{|l|}{ Umur Ibu (tahun) } \\
\hline$<25$ & 6 & 20 \\
\hline $25-35$ & 20 & 66.8 \\
\hline$>35$ & 4 & 13.2 \\
\hline \multicolumn{3}{|l|}{ Tingkat Pendidikan } \\
\hline SD & 1 & 3.3 \\
\hline SMP & 12 & 40 \\
\hline SMA & 14 & 46.7 \\
\hline Diploma & 1 & 3.3 \\
\hline Sarjana & 2 & 6.7 \\
\hline \multicolumn{3}{|l|}{ Tk Pengetahuan } \\
\hline Tinggi & 29 & 96.7 \\
\hline Rendah & 1 & 3.3 \\
\hline \multicolumn{3}{|l|}{ Pekerjaan Ibu } \\
\hline Bekerja & 14 & 46.7 \\
\hline Tidak bekerja & 16 & 53.3 \\
\hline \multicolumn{3}{|c|}{ Keberhasilan Imunisasi } \\
\hline Berhasil & 29 & 96.7 \\
\hline Tidak berhasil & 1 & 3.3 \\
\hline
\end{tabular}

Berdasarkan Tabel 1 di atas diketahui umur bayi berkisar antara 9 sampai 13 bulan dengan rata-rata umur 11.33 bulan dan standar deviasi 0.844 . Sebagian besar bayi berumur 11 bulan (50\%) dan paling sedikit berumur 9 bulan (3.3\%). Umur ibu berkisar antara 24 tahun sampai dengan 47 tahun dan ratarata umur 30.53 tahun dan standar deviasi 5.78. Sebagian besar umur ibu adalah antara 25 - 35 tahun $(66,8 \%)$ dan merupakan usia reproduksi sehat, dan paling sedikit adalah umur $>35$ tahun (13.4\%).

Tingkat pendidikan ibu bervariasi dari lulus SMP sampai sarjana dan dikategorikan menjadi 2 yaitu tingkat pendidikan rendah jika pendidikan terakhir adalah SD sampai dengan SMP dan tingkat pendidikan tinggi jika pendidikan terakhir adalah SMA, Diploma dan Sarjana. Sebagian besar tingkat pendidikan ibu adalah SMA $(46.7 \%)$ dan paling sedikit adalah SD dan Diploma yaitu masing-masing sebanyak 3.3\%.

Tingkat pengetahuan ibu tentang imunisasi bervariasi dengan skor terendah 55 dan skor tertinggi 95 dengan rata-rata 84.67 dan standar deviasi 7.184. Tingkat pengetahuan ibu dapat dikategorikan menjadi 2 yaitu tingkat pengetahuan tinggi yaitu jika skor pengetahuan $>50$ dan rendah jika skor pengetahuan $\leq 50$. Sebagian besar tingkat pengetahuan ibu tentang imunisasi adalah tinggi $(96.7 \%)$ dan ibu dengan tingkat pengetahuan rendah hanya 3.3\%.

Pekerjaan ibu bayi bervariasi dan dikategorikan menjadi 2 yaitu bekerja dan tidak bekerja. Dikatakan bekerja jika ibu memiliki pekerjaan di luar rumah seperti pegawai swasta, PNS dan wiraswasta dan dikatakan tidak bekerja jika mempunyai peran sebagai Ibu Rumah Tangga (IRT). Sebagian besar ibu bayi tidak bekerja (53.3\%) dan hanya $46.6 \%$ yang bekerja.

Keberhasilan imunisasi pada bayi diketahui dari kelengkapan jenis imunisasi yang didapatkan oleh bayi. Keberhasilan imunisasi pada bayi dikategorikan menjadi 2 yaitu berhasil dan tidak berhasil. Dikatakan berhasil apabila bayi mendapatkan semua jenis imunisasi dasar yang meliputi imunisasi BCG, Hepatitis B, DPT, Polio dan Campak secara lengkap dan dikatakan tidak berhasil bila bayi tidak mendapatkan imunisasi dasar tersebut secara lengkap. Sebagian besar bayi berhasil mendapatkan imunisasi secara lengkap yaitu sebanyak 29 bayi $(96.7 \%)$ dan hanya satu bayi 
yang tidak berhasil mendapatkan imunisasi secara lengkap (3.3\%).

Tabel 2

Tabulasi Silang

\begin{tabular}{|c|c|c|c|c|}
\hline \multirow[t]{2}{*}{ Variabel } & \multicolumn{2}{|c|}{$\begin{array}{c}\text { Keberhasilan } \\
\text { Pemberian } \\
\text { Imunisasi Dasar }\end{array}$} & \multirow[t]{2}{*}{ Total } & \multirow[t]{2}{*}{$p$} \\
\hline & Berhasil & $\begin{array}{c}\text { Tidak } \\
\text { berhasil }\end{array}$ & & \\
\hline \multicolumn{5}{|l|}{ Tk Pend. } \\
\hline $\begin{array}{l}\text { Tinggi } \\
\text { Rendah }\end{array}$ & $\begin{array}{l}17 \\
12\end{array}$ & $\begin{array}{l}0 \\
1\end{array}$ & $\begin{array}{l}17 \\
13\end{array}$ & \multirow[t]{2}{*}{0.245} \\
\hline Pekerjaan & & & & \\
\hline $\begin{array}{l}\text { Bekerja } \\
\text { Tidak }\end{array}$ & 14 & 0 & 14 & \multirow{2}{*}{0.341} \\
\hline $\begin{array}{c}\text { Tidak } \\
\text { Tk penget. }\end{array}$ & 15 & 1 & 16 & \\
\hline Tinggi & 29 & 0 & Tk penget. & \\
\hline Rendah & 0 & 1 & 1 & 0.000 \\
\hline
\end{tabular}

Tabel 2 menunjukkan tidak terdapat hubungan tingkat pendidikan dengan keberhasilan pemberian imunisasi pada bayi ( $p=0.245$ ), tidak terdapat hubungan pekerjaan dengan keberhasilan pemberian imunisasi pada bayi ( $p=0.341$ ), dan terdapat hubungan yang secara statistik signifikan antara pengetahuan ibu tentang imunisasi dasar dengan keberhasilan pemberian imunisasi pada bayi ( $p=$ 0.000).

\section{PEMBAHASAN}

Berdasarkan karakteristik responden penelitian diketahui bahwa usia bayi mayoritas adalah 11 bulan yaitu 15 bayi (50\%). Sesuai dengan panduan imunisasi dari Ikatan Dokter Anak Indonesia (IDAI) tahun 2017 bahwa imunisasi dasar wajib yang diberikan terakhir adalah imunisasi campak yang diberikan pada bayi berumur 9 bulan, sehingga jika bayi telah berumur lebih dari 9 bulan seperti mayoritas umur 11 bulan maka imunisasi dasar yang diberikan seharusnya sudah lengkap dan keluarga masih ingat tentang kelengkapan imunisasi bayinya yang belum terlalu lama.

Mayoritas usia ibu adalah antara 25 - 35 tahun yaitu sebanyak 20 ibu $(66,8 \%)$ karena pada umur inilah merupakan usia ideal untuk reproduksi karena menurut Manuaba (2007) jika seorang ibu mempunyai kehamilan berusia kurang dari 20 tahun dan lebih dari 35 tahun mempunyai resiko yang kurang menguntungkan baik bagi bayi dan pada usia 20 - 35 tahun seorang ibu telah benar-benar siap untuk mempunyai anak baik secara anatomi maupun secara fisiologi.

Tingkat pendidikan responden menunjukkan bahwa sebagian besar tingkat pendidikan ibu adalah SMA yaitu sebanyak 14 ibu (46.7\%), dimana hal ini menunjukkan bahwa himbauan Pemerintah berupaya untuk meningkatkan taraf hidup melalui sektor pendidikan bagi setiap warga negaranya sebagaimana tertuang dalam Undang-Undang Sisdiknas No. 20 Tahun 2003 Pasal 3 sebagaimana dikutip oleh Saidah (2016), yang menyatakan bahwa pendidikan berfungsi untuk mengembangkan kemampuan dan membentuk watak serta peradaban bangsa yang bermartabat dalam rangka mencerdaskan kehidupan bangsa, bertujuan untuk berkembangnya potensi peserta didik agar menjadi manusia yang beriman dan bertakwa kepada Tuhan Yang Maha Esa, berakhlak mulia, sehat, berilmu, cakap, kreatif, mandiri, dan menjadi warga negara yang demokratis serta bertanggung jawab. Program Pemerintah tersebut yaitu pendidikan dasar wajib bagi setiap warga negara adalah adalah 9 tahun yang dapat diasumsikan pendidikan sampai tingkat SMP (Sekolah Menengah Pertama). Hal ini diperkuat dengan bukti yaitu hanya 1 ibu saja dengan tingkat pendidikan yang tidak lulus pendidikan dasar wajib yaitu lulus SD (Sekolah Dasar) saja (3.3\%).

Tingkat pengetahuan ibu tentang imunisasi dasar diketahui bahwa tingkat pengetahuan mayoritas adalah tinggi yaitu sebesar 29 ibu 
$(96.7 \%)$ dan hanya 1 ibu dengan tingkat pengetahuan rendah (3.3\%). Hal ini berkorelasi positif dengan tingkat pendidikan ibu dimana mayoritas tingkat pendidikan ibu adalah tinggi dan tingkat pengetahuan ibu adalah tinggi.

Sedangkan status pekerjaan ibu diketahui bahwa sebagian besar ibu bayi tidak bekerja yaitu sebanyak 16 ibu $(53.3 \%)$ dan hanya 14 ibu yang bekerja (46.6\%). Hal ini menunjukkan bahwa dengan adanya bayi yang harus dirawat tersebut maka menuntut waktu yang lebih banyak dari para ibu sehingga banyak dari ibu yang lebih memilih untuk tidak bekerja karena menurut Haryono dan Setianingsih (2014) tidak mudah bagi seorang ibu yang harus merawat bayinya meskipun hal ini bukan merupakan suatu pekerjaan akan tetapi cukup menyita banyak waktu ibu. Meskipun demikian masih banyak pula ibu yang bekerja karena pada hakekatnya bekerja adalah sesuatu yang dilakukan untuk mendapat nafkah, dan ketentuan waktu cutinya telah diatur oleh ketentuan yang dibuat oleh pemerintah melalui Kemenakertrans tahun 2014. Adanya bayi akan meningkatkan pembiayaan dalam sebuah keluarga.

Berdasarkan keberhasilan imunisasi menunjukkan bahwa sebagian besar bayi berhasil mendapatkan imunisasi secara lengkap yaitu sebanyak 29 bayi (96.7\%) dan hanya satu bayi yang tidak berhasil mendapatkan imunisasi secara lengkap (3.3\%). Pada penelitian ini cakupan keberhasilan imunisasi dasar lengkap yang diketahui lebih tinggi dari pencapaian desa Universal Child Immunization (UCl) tahun 2015 di Kabupaten Klaten pada sejumlah 401 desa yaitu sebesar $90 \%$ dan sudah sesuai dengan data yang didapatkan dari Profil kesehatan Kabupaten Klaten tahun 2015, dimana pencapaian
Universal Child Immunization (UCI) yang berdasarkan indikator imunisasi dasar lengkap adalah dengan cakupan minimal 85\%dari jumlah sasaran bayi di desa.

Hasil analisis bivariat menunjukkan bahwa tidak terdapat hubungan tingkat pendidikan dengan keberhasilan pemberian imunisasi pada bayi ( $p=0.245)$. Secara teori tingkat pendidikan seseorang seharusnya akan dapat mempengaruhi perilaku seseorang tersebut yang dalam penelitian ini adalah memberikan imunisasi dasar secara lengkap pada bayinya. Seseorang yang berpendidikan tinggi akan berbeda perilakunya dengan orang yang berpendidikan rendah (Waryana, 2016). Dan menurut Amien (2005) yang dikutip oleh Waryana (2016) secara sederhana menyatakan bahwa, hakekat pendidikan adalah untuk meningkatkan kemampuan manusia agar dapat mempertahankan atau bahkan memperbaiki mutu keberadaanya agar menjadi semakin baik. Akan tetapi karena pemberian imunisasi ini adalah merupakan program yang dicanangkan oleh Pemerintah yang selalu disosialisasikan dan terdapat banyak faktor yang dapat mempengaruhi keberhasilannya dimana menurut hasil penelitian ini justru tidak berhubungan dengan tingkat pendidikan. Terdapat faktorfaktor lain yaitu menurut Riskedas antara lain ibu/orangtua takut anaknya menjadi panas/demam, kondisi anak yang sering sakit, keluarga tidak mengizinkan, tempat imunisasi jauh, tidak tahu tempat imunisasi dan ibu sibuk/repot. Maka hasil penelitian ini juga tidak sesuai dengan Notoadmojo (2012) yang menyatakan bahwa pendidikan dapat berpengaruh terhadap peningkatan kemampuan berusaha atau bekerja, sehingga dapat meningkatkan pendapatan (ekonomi) yang selanjutnya akan 
dapat meningkatkan kemampuan untuk memelihara dan meningkatkan kesehatan misalnya menjaga kesehatan dirinya atau keluarganya dan mencegah terjangkit penyakit seperti mengimunisasikan keluarganya. Hasil penelitian ini juga berbeda dengan hasil penelitian oleh Sya'diyah dan Nursianti (2013) di Puskesmas Baja Kecamatan Cibodas, Kabupaten Tangerang tahun 2012 dengan hasil yaitu 2 faktor yang berhubungan dengan pemberian imunisasi dasar lengkap pada bayi yaitu pendidikan tinggi ibu $(p=0,031)$ dan pemeriksaan kehamilan $\geq 4$ kali $(p 0,036)$, yang berarti semakin tinggi pendidikan ibu dan semakin sering memeriksakan kehamilan, semakin tinggi pemberian imunisasi dasar yang lengkap kepada bayinya. Hasil penelitian juga tidak sama dengan penelitian oleh Thaib, et al. (2013) dengan judul Cakupan imunisasi dasar anak usia 1-5 tahun dan beberapa faktor yang berhubungan di Poliklinik Anak RSIA Banda Aceh yang menyatakan bahwa terdapat hubungan yang bermakna antara sebaran pendidikan ibu dengan kelengkapan imunisasi dasar $(p=<0.05)$. Meskipun berbeda dengan kedua penelitian di atas, tetapi hasil penelitian ini sama dengan hasil penelitian oleh Rahmadhani dengan judul Faktorfaktor yang berhubungan dengan kelengkapan imunisasi dasar balita di Desa Balegondo Kecamatan Ngariboyo Kabupaten Magetan yang menunjukkan variabel pendidikan $(p=0.089)$, pekerjaan $(p=0.813)$, motivasi ibu $(p=0.251)$, tetapi variabel usia ibu justru berhubungan ( $p=0.034)$.

Hasil analisis bivariat juga menunjukkan tidak terdapat hubungan pekerjaan dengan keberhasilan pemberian imunisasi pada bayi $(p=0.341)$. Pekerjaan yang dimaksud dalam penelitian ini adalah segala kegiatan yang dilakukan ibu yang bertujuan untuk mendapatkan uang. Secara teori dengan kegiatan tersebut maka akan mengurangi waktu ibu untuk merawat bayinya termasuk dalam hal memberikan imunisasi dasar secara lengkap. Namun hasil penelitian ini justru menunjukkan tidak terdapat hubungan antara keduanya. Hal ini dimungkinkan karena meskipun ibu bekerja namun para ibu sangat memahami bahwa imunisasi merupakan salah satu cara pencegahan penyakit menular yang sangat penting, khususnya penyakit yang dapat dicegah dengan imunisasi (PD3I) dengan tujuan merangsang sistem imun tubuh untuk membentuk antibodi yang berguna untuk menimbulkan/ meningkatkankekebalan seseorang secara aktif sehingga dapat mencegah atau mengurangi akibat penularan PD3I tersebut (Kementrian Kesehatan RI, 2016). Sehingga hasil penelitian ini tidak sesuai dengan Witley sebagaimana dikutip oleh Mustari (2017), yang menyatakan bahwa sebagian besar kehidupan masa dewasa kita dihabiskan untuk bekerja, memikirkan pekerjaan, membicarakan tentang pekerjaan, dan menghabiskan lebih banyak waktu di kantor daripada di rumah. Menurut kutipan Mustari di atas bisa disimpulkan bahwa apabila ibu bekerja maka waktu ibu untuk keluarga menjadi berkurang, dalam hal ini termasuk waktu untuk menjaga kesehatan dan mencegah penyakit misalnya tidak ada waktu untuk mengimunisasikan anaknya. Hasil penelitian ini juga sama dengan hasil penelitian oleh Rahmadhani dengan judul Faktorfaktor yang berhubungan dengan kelengkapan imunisasi dasar balita di Desa Balegondo Kecamatan Ngariboyo Kabupaten Magetan yang menunjukkan variabel pendidikan $(p=0.089)$, pekerjaan 
( $p=0.813)$, motivasi ibu $(p=0.251)$, tetapi variabel usia ibu justru berhubungan $(p=0.034)$.

Dari hasil analisis bivariat menunjukkan bahwa terdapat hubungan yang secara statistik signifikan antara pengetahuan ibu tentang imunisasi dasar dengan keberhasilan pemberian imunisasi pada bayi $p=0.000$ dan $p<0.05$. Pada penelitian ini didapatkan hasil bahwa mayoritas pengetahuan ibu tentang imunisasi dasar adalah tinggi yaitu 29 ibu (96.7\%). Hasil ini dapat dipahami dimana dengan pengetahuan yang tinggi tentang imunisasi dasar maka ibu mendapatkan pemahaman yang mendalam tentang pemberian imunisasi dasar lengkap pada bayi. Hal ini menunjukkan dengan tingkat pengetahuan yang tinggi akan membawa perilaku untuk memberikan imunisasi dasar pada bayi secara lengkap. Pemberian imunisasi dasar yang terus-menerus disosialisasikan oleh pemerintah dan melalui banyak media maka dimungkinkan para ibu akan semakin sering terpapar sehingga tahu dan mendapatkan banyak informasi. Sesuai dengan teori yang ada bahwa pengetahuan merupakan hasil dari tahu, yang terjadi setelah orang melakukan pengindraan terhadap suatu objek tertentu melalui pancaindra, dimana sebagian besar pengetahuan manusia diperoleh melalui mata dan telinga. Dan pengetahuan atau kognitif ini merupakan domain yang sangat penting dalam membentuk tindakan seseorang (overt behaviour) (Notoadmojo, 2011). Hal ini sesuai dengan penelitian oleh Hindun, Vasra dan Komariah (2009) yang menyatakan bahwa semakin baik pengetahuan ibu maka semakin besar kelengkapan imunisasinya. Hasil penelitian ini juga sesuai dengan penelitian oleh Wadud (2013) yang menyatakan bahwa pengetahuan ibu berbanding lurus dengan kelengkapan imunisasi dasar pada balita. Penelitian ini juga sesuai dengan penelitian oleh Muchtar yang menyatakan bahwa faktor yang berhubungan dengan kelengkapan imunisasi dasar adalah pengetahuan, pendidikan, usia ibu, sikap status sosial ekonomi serta opini orang tua dan vaksin.

\section{KESIMPULAN}

Hasil analisis dengan uji Chi Square menunjukkan tidak terdapat hubungan tingkat pendidikan dengan keberhasilan pemberian imunisasi pada bayi ( $p=0.245$ ), tidak terdapat hubungan pekerjaan dengan keberhasilan pemberian imunisasi pada bayi ( $p=0.341)$, dan terdapat hubungan yang secara statistik signifikan antara pengetahuan ibu tentang imunisasi dasar dengan keberhasilan pemberian imunisasi pada bayi ( $p=$ 0.000).

\section{SARAN}

Masyarakat disarankan untuk selalu aktif dalam mengikuti programprogram Pemerintah seperti dalam menyukseskan pemberian imunisasi agar setiap bayi berhasil mendapatkan imunisasi secara lengkap dan cakupan pemberian imunisasi mencapai 100\% dan tenaga kesehatan disarankan untuk terus-menerus memberikan penyuluhan kesehatan tentang pemberian imunisasi agar pengetahuan setiap orang tua tentang pemberian imunisasi meningkat yang dapat berdampak pada perilaku pemberian imunisasi pada bayi sehingga cakupannya dapat optimal. 


\section{DAFTAR PUSTAKA}

Dinkes Kabupaten Klaten. 2015. Profil Kesehatan Kabupaten Klaten.

http://dinkesklatenkab.com/ Diakses 20 Agustus 2017.

Haryono, R. dan S. Setyaningsih. 2014.Manfaat ASI Eksklusif untuk Buah Hati Anda. Gosyen Publishing, Yogyakarta.

Hindun, Vasra dan Komariah. 2009. Hubungan antara Pengetahuan dan Sikap Ibu dengan Status Kelengkapan Imunisasi Dasar pada Batita di Wilayah Kerja Puskesmas Swakelola Gandus Palembang. http://poltekkespalembang.ac.i d/userfile/files/hubungan antar a pengetahuan dan sikap ib u.pdf. Diakses 20 Agustus 2017.

IDAI. 2017. Jadwal Imunisasi 2017. www.idai.or.id/artikel/klinik/imu nisasi/jadwal-imunisasi-2017. Diunduh 20 Agustus 2017.

Kementrian Kesehatan RI. 2016. Situasi Imunisasi Di Indonesia. Kementrian Kesehatan RI, Jakarta.

Kemenakertrans. 2014. Peraturan Pemerintah No. 24 Tahun 1976 tentang Cuti Pegawai Negeri Sipil. Kemenakertrans, Jakarta.

Kumalasari, I. 2015. Panduan Praktik Laboratorium dan Klinik Perawatan Antenatal, Intranatal, Postnatal, Bayi Baru Lahir dan Kontrasepsi. Salemba Medika, Jakarta.

Manuaba, I.B.G. 2007. Pengantar Kuliah Obstetri. EGC, Jakarta.
Mulyanti, Y. 2013. Faktor-Faktor Internal Yang Berhubungan dengan Kelengkapan Imunisasi Dasar Balita Usia 15 Tahun di Wilayah Kerja Puskesmas Situgintung Ciputat Tahun 2013. Skripsi. Universitas Islam Negeri Syarif Hiyatullah, Jakarta.

Mustari, Idat. 2017. Bekerja Karena Allah. Safina PT Mizan Pustaka, Bandung.

Notoatmodjo, Soekidjo. 2011. Kesehatan Masyarakat IImu \& Seni. Rineka Cipta, Jakarta. . 2012. Promosi Kesehatan dan Perilaku Kesehatan. Rineka Cipta, Jakarta.

Saidah, U. H. 2016. Pengantar Pendidikan Telaah Pendidikan Secara Global dan Nasional. Rajawali Pers, Jakarta.

Suryanti, E. dan A. Badi'ah. 20114. Asuhan Keperawatan Anak Sehat dan Berkebutuhan Khusus. Pustaka Baru Press, Yogyakarta.

Sya'diyah, Y. dan S. Nursianti. 2013. Faktor-faktor yang Berhubungan dengan Kelengkapan Imunisasi Dasar pada Bayi di Puskesmas Baja Kecamatan Cibodas Kabupaten Tangerang Banten. Jurnal IImiah Permata MEDIKA. Volume 2 No. 1. Diunduh 20 Agustus 2017.

Thaib, T.M., D. Darussalam, S. Yusuf dan R. Andid. 2013. Cakupan Imunisasi Dasar Anak Usia 1-5 Tahun dan Beberapa Faktor yang Berhubungan di Poliklinik Anak Rumah Sakit lbu dan Anak (RSIA) Banda Aceh. Sari Pedriatri. Volume 14 Nomor 5. Diunduh 20 Agustus 2017. 
••KOsคเค•• JIK. Vol. 6 No. 2 November 2018

Wadud, M. A. 2013. Hubungan antara Pengetahuan dan Pekerjaan Ibu dengan Status Imunisasi Dasar pada Bayi di Desa Muara Medak Wilayah Kerja Puskesmas Bayung Lencir.

http://poltekkespalembang.ac.i d/userfiles/files/hubungan ant ara pengetahuan dan pekerj aan ibu dengan status imuni sasi dasar pada bayi di des a muara medak wilayah kerj a puskesmas bayung lencir 2013.pdf. Diunduh 20 Agustus 2017.

Waryana. 2016. Promosi Kesehatan

Penyuluhan dan Pemberdayaan Masyarakat. Nuha Medika, Yogyakarta.

${ }^{1}$ Dosen Akper Panti Kosala

Surakarta

${ }^{2}$ Mahasiswa Akper Panti Kosala

Surakarta 